\title{
Current status of economically important diadromous fish species of Turkey; European eel, Black Sea trout and sturgeon species
}

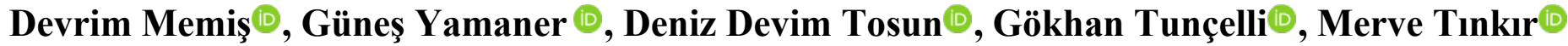

Cite this article as:

Memiş, D., Yamaner, G., Tosun, D.D., Tunçelli, G., Tınkır, M. (2020). Current status of economically important diadromous fishspecies of Turkey; European eel, Black Sea trout and sturgeon species. Aquatic Research, 3(4), 188-196. https://doi.org/10.3153/AR20017

Istanbul University Faculty of Aquatic Sciences, 34134, Laleli, İstanbul, Turkey

\section{ORCID IDs of the author(s):}

D.M. 0000-0001-7378-0165

G.Y. 0000-0003-1886-4985

D.D.T. 0000-0001-6612-6624

G.T. 0000-0003-1708-7272

M.T. 0000-0003-2807-2789

Submitted: 22.04 .2020

Revision requested 13.05.2020

Last revision received 17.05.2020

Accepted: 01.06.2020

Published online: 17.06 .2020

Correspondence: Devrim MEMIŞ

E-mail: $\underline{\text { mdevrim@istanbul.edu.tr }}$

\section{ABSTRACT}

Turkey has a rich variety of fish species in its rivers with a total length of $177714 \mathrm{~km}$. Freshwater fish live in rivers, streams, creeks, dam lakes, natural lakes, wetland areas, etc.

The life of migratory fish is threatened by the anthropogenic impact on aquatic habitats. Human activities that disrupt river integrity can be listed as; dam and hydro power plant constructions, high levees, sluices, weirs and bridges, sand-gravel quarries, recreational works, wetland depletion, water pollutions, overfishing, habitat losses, climate changes, water pumping from a river to other river basins, drinking water, dried river beds etc. The most important diadromous fish species in Turkey are sturgeon species (Acipenseridae), European eel (Anguilla anguilla) and Black Sea trout (Salmo trutta labrax). In this study, the past and present status of these species are reviewed.

Keywords: European eel, Black Sea Trout, Sturgeon species, Endangered, Recovery

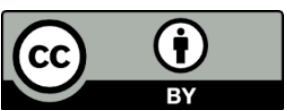

(C) 2020 The Author(s)

Available online at

http://aquatres.scientificwebjournals.com 


\section{Introduction}

Diadromous fish are described as fish that prefer to live in both inland freshwaters and marine habitats depending on their life cycles. They are categorized as anadromous and catadromous fish. Anadromous fish are the ones that breed in inland freshwaters and migrates to the seas to spend their adult lives till the point at which they return to freshwaters for breeding. On the contrary, catadromous fish are the ones that breed in marine habitats and return to freshwater for growth and development until they migrate to breeding grounds. Salmonids come to mind as an example for anadromous fishwhereas eels are a well-known catadromous fish species (Gross et al 1988; McDowall, 1988).

Fish migration terminology, explains how fish move among marine, estuarine, and freshwater environments (e.g., anadromy, catadromy, marine residents, estuarine stragglers, etc.). Such terms are useful in describing broad patterns of habitat use and can aid in species and habitat conservation efforts. For instance, knowing that an anadromous sturgeon requires unimpeded access to large rivers for reproduction leads to an emphasis on dam removal in their conservation (Secor, 2015). Anadromous fish are more common in temperate regions of the world where oceans are more productive in terms of food availability. Yet, in tropical latitudes, freshwater habitats are more productive and this results in common dispersal of catadromous fish (Gross et al., 1988).

Turkey has 409 freshwater fish species and $47.4 \%$ of them are endemic. There are 33 rivers with a total length of $177714 \mathrm{~km}$ and 25 river basins such as rivers, dam lakes, natural lakes, etc in Turkish water system. Some diadromous fish species in the aquatic system are; Salmo trutta labrax, Acipencer stellatus, Acipenser gueldenstaedtii, Huso huso, Anguilla anguilla, Atherina boyeri, Lampetra lanceolata, Alosa fallax, Mugil cephalus and Platichthys flesus, etc. (Çiçek et al., 2018; Ekmekçi et al., 2016).

Main anadromous species like Salmonids and sturgeon species are dispersed in the Black Sea region, migrating from sea to the freshwater where spawning occurs and also catadromous eels (European eel, Anguilla anguilla) are found in the West Black Sea and Mediterranean region entering the rivers for feeding and growing. In this review paper, the situation of the most important three diadromous fishes in Turkey is summarized and evaluated.

\section{Sturgeon Species in the Black Sea Basin (Acipenser sp., Huso sp.)}

The sturgeons (Acipenseridae) constitute one of the oldest orders of fish still in existence. Six species of sturgeon are reported in the Turkish Black Sea basin and its drainage area:
Beluga (Huso huso), Russian sturgeon (Acipenser gueldenstaedtii), common sturgeon ( $A$. sturio), ship sturgeon ( $A$. nudiventris) and stellate sturgeon (A. stellatus) and sterlet sturgeon (A. ruthenus). These species are known to migrate into large rivers like Sakarya, Yeşilırmak, Kızılırmak and Çoruh Rivers to spawn and they are naturally present in the northern part of the Anatolian peninsula and Trakya. Until 1970's sturgeons were economically important in the Black Sea region and were known to have an important fishing potential mainly in Çarşamba, Bafra, Karasu and Istanbul (Arısoy, 1968; Çelikkale, 1994; Rosenthal et al., 2015; Ustaoğlu Tırıl and Memiş, 2018). Edwards and Doroshov (1989) reported that A. sturio, Huso huso, A. gueldenstaedti, A. stellatus and $A$. nudiventris were found in the fishing ports of the Turkish coast. And also, they stated, the most common species of sturgeons were $A$ sturio and $H$. huso in the past.Turkey signed CITES agreement at 22 December 1996 and all sturgeon fisheries were banned after 1 April 1998.Until today, the situation has completely changed and sturgeons are at the brink of extinction in Turkish waters. It is known that anthropogenic impacts like over-fishing, construction of dams and HPPs (Hydro Power Plants), flood control barriers and pollution in rivers played a very significant role in the depletion of wild populations of migratory fish species (Rosenthal et al., 2015; Ustaoğlu Tirıl and Memiş, 2018).

Reported sturgeon species number had fallen to five (H. huso, A. nudiventris, A. gueldenstaedtii, A. stellatus, A. sturio) by late 1980'ies (Edwards and Doroshov, 1989). Three of these, H. huso, A. gueldenstaedtii and A. stellatus, were observed till 2000'ies, and are studied and reported by researchers (Celikkale et al., 2003; Zengin et al., 2008, Memis, 2014).

Beluga (H. huso) is a well-known species from the Caspian Sea, Black Sea, Azov Sea and the Adriatic Sea basins. This species vanished from the Adriatic and Azov Seas because of overexploitation and destruction of breeding grounds due to dam constructions. It is an anadromous native fish species for Azerbaijan; Bulgaria; Georgia; Iran; Moldova; Romania; Russian Federation; Serbia and Turkey. In spring, sturgeons migrate from the Black Sea to the Turkish rivers such as Yeşilırmak, Kızılırmak, Sakarya and Çoruh Rivers.

Russian sturgeon (A. gueldenstaedtii) is another native anadromous sturgeon species in Turkey. This species originates from the Caspian Sea, Black Sea and Azov Sea basins. This species is currently reported from the Caspian Sea where it breeds in the rivers Ural and Volga, and the Black Sea where breeding grounds are located in the lower Danube and Rioni rivers and Sakarya River (Kolman and Zarkua, 2002). Presently, the species is not abundant in the Black Sea basin and 
Turkish rivers mostly because, almost all of the species' breeding grounds had been damaged and lost due to human made obstructive constructions.

Stellate sturgeon (A. stellatus) inhabits the Caspian Sea, Black Sea and Azov Sea, and rarely reported from the Aegean Sea. The Volga, Ural, Terek, Sulak, Kura, Don, Danube, Kuban and Sakarya River are the major breeding grounds of this species (Chebanov and Galich, 2013). The reason for decreasing in the wild population of stellate sturgeon is primarily due to marine over-fishing, especially increased catch of large and mature sturgeon resulting in fewer individuals that can successfully reproduce. Some of the sturgeon species are amongst the largest fish in the world, and they produce one of the most valuable natural resource, caviar. Therefore, sturgeons have been heavily exploited by the surrounding countries of the Black Sea even till the present time.

The earliest reports about sturgeon fishing in Turkey are from the early 1950'ies, which intensified rapidly during the 1960s. Archives from Istanbul Kumkap 1 fish market from the late 1960'ies and 1975 shows that landings reached 300 tons per annum. But, landings declined rapidly towards the end of the 1960s but increased sharply in the early 1970s reaching previous levels. Annual caviar production from these catches reached over 8 tons/year in the 1970s. Catches dropped rapidly under ten tons after 1975 and the sturgeon fishery almost collapsed. This sharp decline was not just due to the decreased fishing effort but also due to a lack of available fish. This indicated that increments in landing during early 1970 were a result of increasing fishing effort. The sturgeons used to enter and spawn in major rivers, namely Kizılırmak, Yeşilırmak and Sakarya, running into the Black Sea. There are few specimens still entering or trying to enter these rivers. Yeşilırmak River is a major river located at the province of Samsun and is used by most of the migratory species, while the River Sakarya situated in the western part of the Turkish Black Sea coast is also still used by species such as Stellate, Russian sturgeon and Beluga. According to the Convention on International Trade in Endangered Species of Wild Fauna and Flora (CITES), sturgeon fishing is banned after 1 April 1998 in Turkey (Celikkale et al., 2003; Zengin et al., 2008, Memiş, 2014).

Ministry of Agriculture and Forestry conducted a Restocking Program for sturgeons in 2011 (Rosenthal et al., 2015). 5500 individual Russian sturgeons and 4500 individual stellate sturgeon were tagged and released to Yeşilırmak and Sakarya River in 2011. About 250-tagged sturgeon were reported after releasing. \% 2.5 sturgeon were informed by the fishermen. Tagged sturgeon information was from Bulgaria/Burgaz to Georgia/Batum. Besides, a few sturgeon were reported from the Marmara Sea.

Memiş et al. (2019) reported that a wild young A. stellatus was caught on August 2014 in the freshwater section of Sakarya River, close to the river mouth. This wild specimen was too small $(25 \mathrm{gr})$ to migrate long distances in the marine environment which suggested that mature stellatus had spawned in the lower Sakarya river (Khodorevskaya et al., 2009; Memiş et al. 2019) Thus, this river must be protected and reopened for migration till up-stream of Adasu Hydro Power Plant. And also this Hydro Power Plant which has dysfunctional fish passages should be revised for sturgeon species at least for A.stellatus. According to Anon. (2018a) there is an urgent need for coordinated efforts and centralized facilities in order to save this species which may be the last living sturgeon species in Lower Sakarya River habitat.

\section{Black Sea Trout (Salmo trutta labrax)}

Salmonidae family members are dispersed in the northern hemisphere and brown trout is naturally distributed from Norway, Northeast Russia down to Northern African Atlas Mountains. The distribution and evolution of brown trout as a species is influenced by the latest ice age in Europe between 70000 - 10000 B.C. (Behnke, 1972; Berg, 1985; Bernatchez, 2001; Berra, 2001; Çiftçi, 2006; Kocabaş, 2009) (Figure 1).

Trout species are widely distributed in clean, clear and cold waters where oxygen is abundant and these fish are both important in terms of recreational fisheries and commercial production, so their wild stocks are supported systematically. It was reported that Salmo trutta spp. had been carried to 24 different countries to support natural stocks during 1852 1938 (Klemetsen et al. 2003). Salmo trutta labrax is an indigenous species in Turkey (Aras, 1976; Geldiay and Balık, 1988; Arslan et al., 2000; Kuru, 2004; Kocabaş, 2009).

Salmo trutta has been classified according to their ecology and phenotypes under different species and sub-species (Figure 2) (Kocabaş, 2009). Berg (1962) was the first to describe Black Sea trout (Salmo trutta labrax) in the Black Sea (Arıman and Kocaman, 2003). Turan et al., (2009) divided Black Sea trout into two species according to their molecular and morphometric characteristics. They defined Salmo trutta labrax (Black Sea trout) as Salmo coruhensis (Çoruh trout) and Salmo trutta macrostigma as Salmo rizeensis (mountain trout or red spotted trout). 


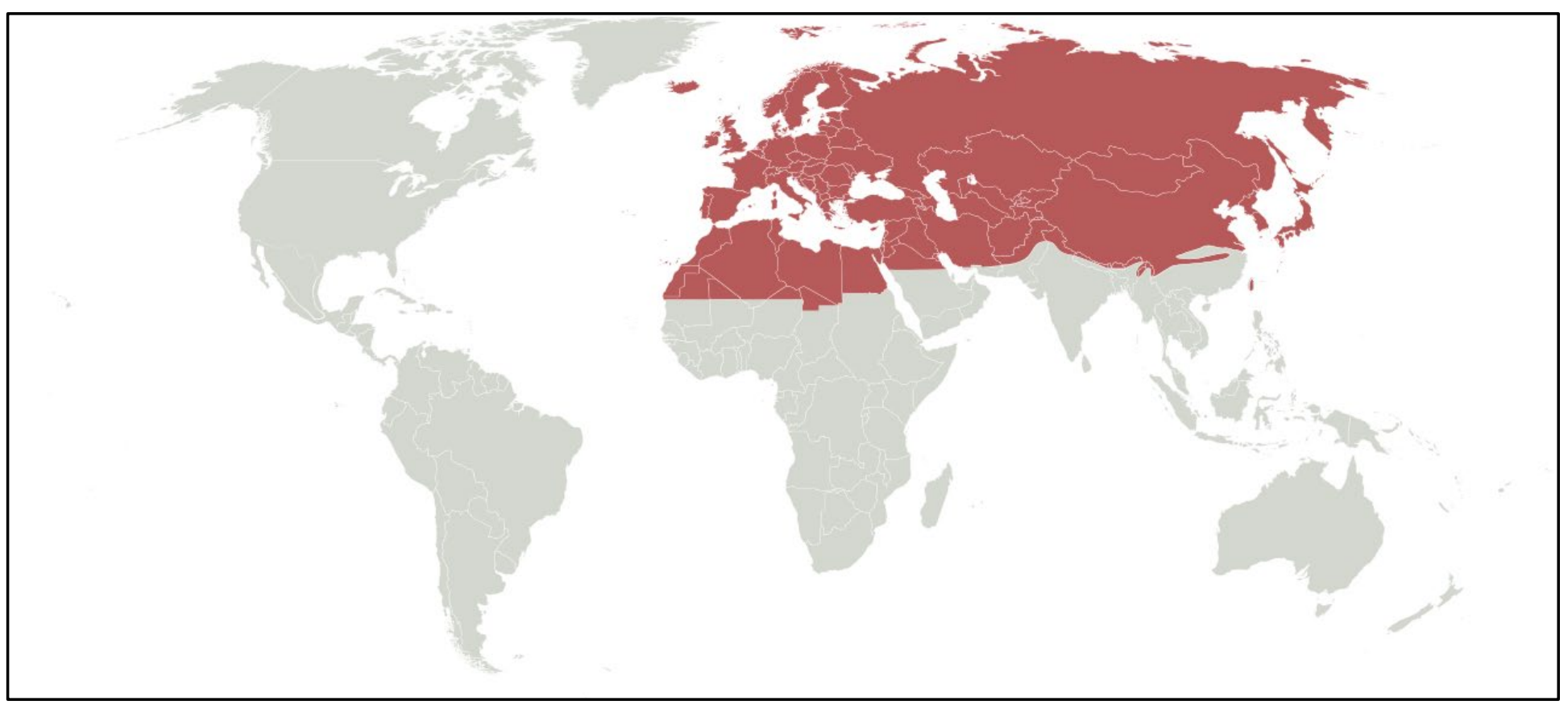

Figure 1. Distribution of Salmo trutta, Palearctic Region (red) (Anon., 2016).

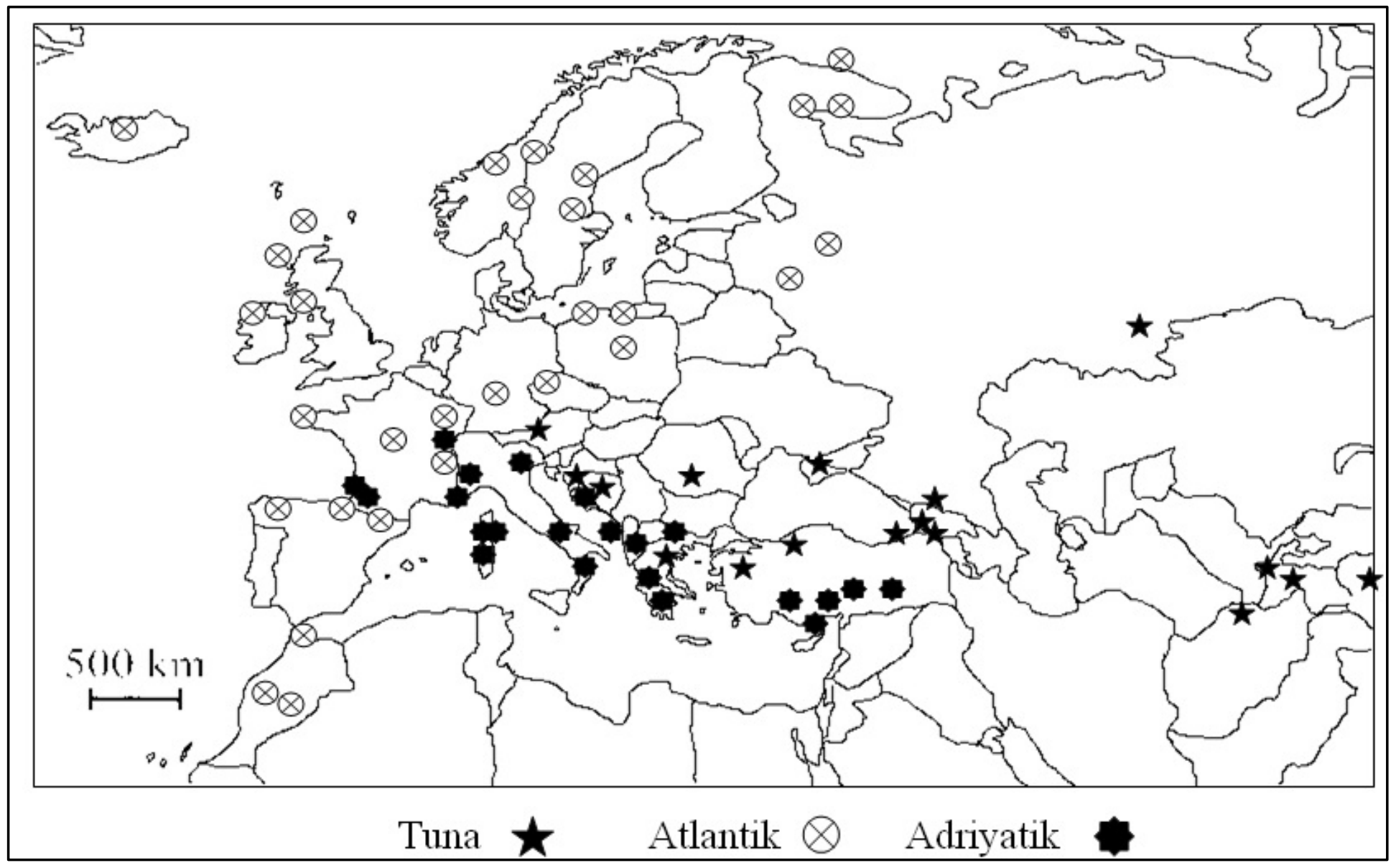

Figure 2. Geographic distribution of different strains (Kocabaş, 2009). 
Black Sea trout is accepted as an important rival for Oncorhynchus mykiss (rainbow trout) with its appealing appearance, fast growth, high meat yield and commercial value. As it is an indigenous fish and its natural habitat is under pressure. Black Sea trout has become an important species in aquaculture in the recent years (Elliott, 1994, Kocabaş, 2009; Turan et al., 2009; Tunçelli and Memiş, 2020). Natural stocks of this species are fished to its limits with illegal methods, breeding and feeding grounds are destroyed by human activities and water pollution resulted in endangered species status (IUCN red list) (Aydın and Yand1, 2002). According to Turkish Government Fishing Rules, Black Sea trout (Salmo trutta labrax, syn Salmo coruhensis) fishing is banned whole year round (Statement Number: 2016/36). As a result, academic, governmental and commercial trials on Black Sea trout (Salmo trutta labrax) have gained speed (Aksungur et al., 2007; Başçınar et al., 2007; 2010a, 2010b). A restocking program for Black Sea trout is managed by Ministry of Agriculture and Forestry. Tagged fishes is released to the rivers where their natural living areas by the General Directorate of Nature Conservation and National Parks and the General Directorate of Fisheries and Aquaculture (Table 1) (Anon., 2013; Anon., 2019). A joint restocking program was also carried out with Istanbul University Faculty of Aquatic Sciences and Ministry of Agriculture and Forestry where a total 15000 Black Sea trout were released to the Akçay River in Sakarya Province in 2018. All released fishes was tagged with visible implant elastomer tag which was in yellow and red colors (Anon., 2018b).

Table 1. Salmonid Restocking Program (Ministry of Agriculture and Forestry)

\begin{tabular}{ccc}
\hline Year & Region & $\begin{array}{c}\text { Number of } \\
\text { released fish }\end{array}$ \\
\hline $2010-2017$ & $\begin{array}{c}\text { Turkey } \\
\text { (Trabzon, Rize, } \\
\text { Gümüşhane, Artvin etc.) }\end{array}$ & 14528500 \\
\hline \multirow{3}{*}{2018} & $\begin{array}{c}\text { South Marmara Region } \\
\text { (Akçay River in Sakarya } \\
\text { Province) }\end{array}$ & 15000 \\
\hline
\end{tabular}

Mostly, private private establishments in the eastern Black Sea region of Turkey started the commercial production of this species with compliance to national regulations. Aquaculture practices are very important for the survival of this endangered trout species (Freyhof, 2013).

\section{European Eel in Turkey (Anguilla anguilla)}

The European eel is a catadromous fish; breeding at sea and spending its growing period in freshwater. It is known to breed in the South West Atlantic Ocean in the region of the Sargasso Sea. The natural distribution of the European eel (Anguilla anguilla) is in inland freshwater habitats near the North Atlantic, Baltic and Mediterranean Seas. It has been introduced to Asia, South and Central America. Males spend 6 to12 years in freshwater whereas females stays in inland waters for 9 to 20 years. They choose to populate river bottoms, beneath the stones, in the mud or in the crevices. After spending their adult time in freshwater habitats, sexually maturation is reached and they start their migration to the Sargasso Sea (McClave et al., 1988, Moriarty and Dekker 1997). It is reported that panmicitic population of the eels are in decline since 1980'ies. Global climate change and its effect on marine habitats like shifts in Gulf Stream result in reduced survival rate for the leptocephali during their migration to freshwater habitats. Combined with overfishing, migration route blockage by man-made obstructions, habitat losses and environmental pollution, loss of global population is inevitable (Feunteun, 2002, Dekker 2003).

The larval eel, known as leptocephali, cross the ocean from west to east before entering European coastal waters. The Gulf Stream carries the leptocephali to the coast of Europe. During this migration, they metamorphose into the transparent glass eels. This drifting migration lasts up to three years. Most glass eels continue their migration to estuaries and then to the fresh water habitats. At this stage, actively swimming upstream, the glass eels undergo es another metamorphosis, their color darkens as pigmentation develops, and are known as elvers from that point. These elvers become small eels before entering freshwater habitats (Tesch, 1977; Keith et al., 1992; Dekker, 2002).

Eels are commercially important in the world. The most valued product is smoked eel which is widely accepted around the world. Eels were captured by fyke nets in the past and kept in clean water to cleanse the muddy odor in ponds before the trade to European countries (Geldiay and Balık, 1988). Eels are present in Turkish rivers and streams draining into the Marmara Sea, the Mediterranean Sea, the Aegean Sea and the Black Sea and also in the lakes connected to these seas. It was reported that this fish was found in Amik Lake, Asi River, Özlen Creek (Karadere, Fethiye), Manavgat, Aksu and Alara rivers in Turkey during 1960'ies to 1970'ies (Geldiay and Balık, 1988; Arslan et al., 2000; Oray, 1987; İkiz et al., 1998; Güven et al., 2016).

The monitoring of the glass eel collection in two Turkish regions are proposed by the Turkish Ministry of Agriculture 
and Forestry, one in the south-western region and another in the south-east of the Mediterranean Region. Özlen Creek/ Fethiye, is located in the south-west of Turkey. This small creek (total length $5 \mathrm{~km}$ ) flows into the Mediterranean Sea. Elvers can be collected using traps, mesh-nets, blanket nets, fine meshed seine net and various other traps.

The Asi River Basin is located in the south-east of Turkey (380 km river length). Recruitment monitoring is possible on the coast at Samandağı. About $50 \mathrm{~km}$ from the sea, at Demirköprü, a bridge crosses the River Asi. The river is 35$40 \mathrm{~m}$ wide and $0.3-2.5 \mathrm{~m}$ deep and the mean annual flow is $15.5 \mathrm{~m}^{3} / \mathrm{s}$. At this site, a trap for yellow eel could easily be built. About $116 \mathrm{~km}$ from the sea, at Tahtaköprü, there is a dam and reservoir built in the river Karasu, a tributary of the Asi River. At this place, there is a dam with $43.50 \mathrm{~m}$ high (from the river bed). The migration of eel over this dam is impossible. Thus, building an eel ladder and a trap is possible on this dam, these locations are potential areas for the monitoring of eel migration in Turkey (Dekker, 2002).

Eels migrate to Bafa Lake (Muğla) via Büyük Menderes River (about $35 \mathrm{~km}$ ) and arrive in Bafa Lake in May-June. From October to November adult eels start their returning voyage back to Mediterranean Sea. Seven-ton European eel was exported to South Korea in 2017. Eel export is organized by S.S. Serçin Fishery Cooperation from Bafa Lake (Personal communication with President of Serçin Fishery Cooperation, 2018). Local fishermen reported that $4 \mathrm{~kg}$ eels from Bafa Lake were caught in the past yet presently maximum caught fish are 1.5 to $2 \mathrm{~kg}$.

European eel (Anguilla anguilla) has no fishery regulations in Turkey. But according to CITES, there are export quotas and eel catch is determined as $100.000 \mathrm{~kg}$ in 2020 by The Ministry of Agriculture and Forestry. Also, eel catching below $50 \mathrm{~cm}$ is forbidden (Statement number: 2016/35). Özden et al. (2018) reported that European eels (Anguilla anguilla) were caught by fyke nets in the Asi River in the south-east of Turkey. The aim of this study was to determine some toxic metals $(\mathrm{Hg}, \mathrm{Pb}, \mathrm{Cd}$ and $\mathrm{As})$ in the flesh of captured eels. According to the data, they did not a find toxic level of metals and it can be said that there is no risk for the consumers.

Küçük et al. (2016) reported the population decline of elvers in natural habitat mainly at the Antalya Bay, Kardelen Stream, Alara River, Karpuz Stream, Manavgat River, Ilıca Stream, Sarısu Stream, Köprüçay River, Aksu Stream, Boğa Stream, Alakır River, Eşen Stream and Gözlen Creek (Fethiye-Muğla). Their observation showed that the eel population completely vanished from these parts of the region due to the interruption of elver passages towards middle and upper sections of large rivers between 2014 and 2016. As reported by scientists around the world, there is a steep decline in wild eel populations similar to the global fisheries measurements, since the early 1980 'ies. The situation is not different in Turkey. If suitable catching methods have been selected and adapted to the local circumstances at the selected stations this can help monitoring and management of eel stock in the rivers (Dekker, 2002).

There is a lack of experimental studies on eel culture although chemical and physical water parameters are suitable for this species and commercial production is not much practiced in Turkey. Recently, two projects about eel culture had been proposed and managed by the Ministry of Agriculture and Forestry via Mediterranean Fisheries Research Production and Training Institute (Antalya) in Turkey.

The project, "Culture of European eel (Anguilla anguilla L. 1758) under controlled conditions (Duration: 01.01.2018 31.12.2019)" aims to obtain sperm and eggs, achieve fertilization, hatching, feeding and on growing of eels. The second Project is "Habitat characteristics and population parameters for eels in Köyceğiz and Beymelek Lagoons (Antalya) and Dalaman and Ozlen Rivers (Muğla) (Other rivers which pour to the Mediterranean are added to this project)" 011.01.201731.12.2018 (time extended). The project's aim is to collect valuable data on sustainable fisheries management of European eel which is widely spread in Turkish inland waters with its high economic and ecologic value. Although there are many studies conducted on eels, available data on this fish lacks many important aspects to ensure a sustainable fisheries management of this species.

\section{Conclusions}

The main threats for diadromous species can briefly be classified as; habitat loss (dam construction, gravel extraction, pollution, river flow regularization, discharge reduction), overfishing (sea, estuaries and rivers) and climate changes (global warming). Diadromous fish need a structural approach to meet the conservation targets in Turkey. The strategy is to provide clear and realistic choices and statements on priority Rivers, most important fish migration routes, target species and fishing quotas. Especially for the endangered diadromous fish, there is a need for the revision of the rules, legislations, bans and ways of stock enhancement by aquaculture.

River connectivity has been shown to be increasingly important for the conservation of native biodiversity and is necessary to ensure healthy migratory fish populations. In the whole world, there are issues with river connectivity, caused by river barriers, influencing the life cycle and population status of migratory fishes. Around the world, researchers and governors have been working for many years to improve the situation for migratory fish by developing the efficiency of 
fish passages, dams or weirs removal, river rehabilitation, improve political and public awareness and exploring other solutions. We need a strong legislation for the protection of diadromous fish and maintaining healthy ecosystems.

\section{Compliance with Ethical Standard}

Conflict of interests: The authors declare that for this article they have no actual, potential or perceived conflict of interests.

Ethics committee approval: -

Funding disclosure: -

Acknowledgments: -

\section{References}

Aksungur, M., Alkan, A., Zengin, B., Tabak, I., Yilmaz, C. (2007). The effect of some environmental parameters on migration patterns of Black Sea trout in fresh water in Eastern Black Sea Region. Ekoloji, 17(65), 28-35.

https://doi.org/10.5053/ekoloji.2007.655

Anonymous (2013). Black Sea trout (Salmo coruhensis (Syn. Salmo trutta labrax) species conservation action plain in Rize province. T.R. Ministry of Forestry and Water Affairs, General Directorate of Nature Conservation and National Parks, Ankara.

Anonymous (2016). Palearktik bölge, https://tr.wikipedia.org/wiki/Palearktik bölge (accessed 10.11 2016).

Anonymous (2018a). Pan-European Action Plan for Sturgeon. Convention on the Conservation of European Wildlife and Natural Habitats. Standing Committee 38th Meeting Strasbourg, 27-30 November 2018. Document prepared by the World Sturgeon Conservation Society and WWF, Strasbourg, France.

Anonymous (2018b). Sapanca Akçay Deresine kırmızı benekl1 alabalı birakıldı. Sapanca Haber, https://www.sapanca.com.tr (20.07.2018).

Anonymous (2019). Su ürünleri istatistikleri. Balıkçılık ve Su Ürünleri Genel Müdürlügü, Ankara. https://www.tarimorman.gov.tr/sgb/Belgeler/SagMenuVeriler/BSGM.pdf $(15.05 .2020)$

Aras, M.S. (1976). Çoruh ve Aras havzası alabalıkları üzerinde biyo-ekolojik araştırmalar. Atatürk Ünversitesi Ziraat Fak. Dergisi, 7(1), 1-16.
Arıman, H., Kocaman, E.M. (2003). Aras, Yukarı Firat ve Çoruh havzaları'nda yaşayan alabalık (Salmo trutta L.)' ların özellikleri. Atatürk Üniversitesi Ziraat Fakültesi Dergisi, 34(2), 193-197.

Arısoy, S. (1968). Fisheries in Sakarya (Sakarya vilayeti çevresinde su ürünleri ekonomisi ve kooperatifleşme ile kalkınma imkan ve problemleri). Istanbul University Economics Faculty Publication, (1391), p. 182.

Arslan, M., Aras, N.M., Yıldırım, A. (2000). Doğal alabalığın Cenker Çayı (Çoruh Havzası)'nın populasyon yapısı ve büyüme özellikleri. Su Ürünleri Sempozyumu, p. 266-278, 22-24 Eylül 2000, Sinop.

Aydın, H., Yandı, İ. (2002). Karadeniz alası (Salmo trutta labrax Pallas, 1811)'nın Doğu Karadeniz bölgesi'nde yumurtlama alanlarının durumu. Ege Üniversitesi Su Ürünleri Dergisi, 19, 3-4.

Başçınar, N., Çakmak, E., Çavdar, Y., Aksungur, N. (2007). The effect of feeding frequency on growth performance and feed conversion rate of Black Sea trout (Salmo trutta labrax Pallas, 1811). Turkish Journal of Fisheries and Aquatic Sciences, 7(1), 13-17.

Başçınar, N., Kocabaş, M., Şahin, A.Ş., Okumuş, I. (2010a). Comparison of hatching performances and yolk sac absorptions of Black Sea trout (Salmo trutta labrax Pallas, 1811), brook trout (Salvelinus fontinalis Mitchill, 1814) and their hybrids. Kafkas Universitesi Veteriner Fakültesi Dergisi, 1(5), 205-209.

Başçınar, N., Şahin, Ş., Kocabaş, M. (2010b). Effect of duo-culture on growth performance of brook trout (Salvelinus fontinalis Mitchill, 1814) and Black Sea trout (Salmo trutta labrax Pallas, 1811) in tank reared condition. Kafkas Universitesi Veteriner Fakültesi Dergisi, 16(3), 249-254.

Behnke, R.J. (1972). The systematics of salmonid fishes of recently glaciated lakes, Journal of the Fisheries Board of Canada, 29(6), 639-671.

https://doi.org/10.1139/f72-112

Berg, L.S. (1962). Freshwater fishes of the USSR and adjacent countries: Ryby presnykh vod SSSR i sopredel'nykh stran (Vol. 1). Israel Program for Scientific Translations; (available from the Office of Technical Services, US Dept. of Commerce, Washington). 
Berg, O.K. (1985). The formation of non-anadromous populations of Atlantic salmon, Salmon salar L., in Europe. Journal of Fish Biology, 27 (6), 805-815.

https://doi.org/10.1111/j.1095-8649.1985.tb03222.x

Bernatchez, L. (2001). The evolutionary history of brown trout (Salmo trutta L.) inferred from phylogeographic, nested clade, and mismatch analyses of mitochondrial DNA variation. Evolution, 55(2), 351-379.

https://doi.org/10.1111/j.0014-3820.2001.tb01300.x

Berra, T.M. (2001). Freshwater fish distribution. p, 604 California, USA, Academic Press. ISBN: 0-12-093156-7.

Çelikkale, M.S., Memis, D., Ercan, E. (2003). Sturgeon culture in Turkey. International Symposium of Fisheries and Zoology, 1 - 04 Ekim 2003, Istanbul.

Çelikkale, M.S. (1994). İç su balıkları yetiştiriciliği.Karadeniz Teknik Üniversitesi Yay.., No: 2, p.419 Trabzon.

Chebanov, M.S., Galich, E.V. (2013). Sturgeon hatchery manual. FAO Fisheries and Aquaculture Technical Paper No: 558, Ankara.

Çiçek, E., Fricke, R., Sungur, S., Eagderi, S. (2018). Freshwater fishes of Turkey; a revised and updated annotated checklist, Biharean Biologists, 9 (2), 141-157.

Çiftçi, Y. (2006). Türkiye alabalık (Salmo trutta Linnaeus, 1758 ve Salmo platycephalus Behnke, 1968) populasyonlarının genetik yapısının mtDNA-RFLP analiz yöntemiyle belirlenmesi, Doktora Tezi, Karadeniz Teknik Üniversitesi Fen Bilimleri Enstitüsü, Balıkçılık Teknolojisi Mühendisliği A.B.D., Trabzon.

Dekker, W. (2002). Monitoring of glass eel recruitment. Netherlands Institute of Fisheries Research, report C007/02WD, p. 256.

Dekker, W. (2003). Did lack of spawners cause the collapse of the European eel, Anguilla Anguilla?. Fisheries Management and Ecology, 10(6), 365-376.

https://doi.org/10.1111/j.1365-2400.2003.00352.x

Edwards, D., Doroshov, S. (1989). Appraisal of the sturgeon and sea trout fisheries and proposals for a rehabilitation programme. F.A.O., p. 37, Rome.

Ekmekçi, F.G., Yoğurtçuoğlu, B., Freyhof, J. (2016). Türkiye'de barajların doğrudan ve dolaylı etkileri nedeniyle tehdit altında olan tatlısu balıkları. Balık Geçitleri ve Göçleri Çalıştayı, 21-22 Kasım 2016, İstanbul.

Elliott, J. M. (1994). Quantitative ecology and the brown trout. Oxford University Press. ISBN: 0198546785

Feunteun, E. (2002). Management of European eel population (Anguilla anguilla): an impossible bargain. Ecological Engineering, 18(5), 575-591.

https://doi.org/10.1016/S0925-8574(02)00021-6

Freyhof, J. (2013). Salmo labrax the IUCN red list of threatened species 2013, e.T135658A4172650.

http://dx.doi.org/10.2305/IUCN.UK.2008.RLTS.T135658A

4172650.en (accessed 06.04.2018).

Geldiay, R., Balık, S. (1988). Türkiye tatlı su balıkları. Ege Üniversitesi Fen Fakültesi Kitaplar Serisi (97), 1-159.

Gross, M. R., Coleman, R. M., McDowall, R. M. (1988). Aquatic productivity and the evolution of diadromous fish migration. Science, 239(4845), 1291-1293.

https://doi.org/10.1126/science.239.4845.1291

Güven, E., Yıldız, M., Baltacı, M.A. (2016). Kırmızı benekli (Salmo trutta sp.) alabalık yumurtalarının inkübasyonu ve yavruların beslenmesi üzerine bir araștırma, Ege Journal of Fisheries and Aquatic Sciences, 33(3), 209-216. https://doi.org/10.12714/egejfas.2016.33.3.04

İkiz, R., Küçük, F., Gülyavuz, H., Gülle, İ. (1998). Antalya Korfezi'ndeki akarsulara (Manavgat Irmağı, Köprüçay Irmağ 1 Aksu ve Alara Çayları) giren yılan balığ (A. anguilla L., 1758) elverlerinin giriş mevsimlerinin tespiti ve yakalama metotları. Tübitak Proje Raporu, YDABÇAG-314, p. 28 .

Keith, P., Allardi, J., Moutou, B. (1992). Livre rouge des espéces menacée de paissons d'ean douce de France et bilan des introductions. Museum National d'Histoire Naturelle, Secretariat de la Faune et del a Flore, Consil Supérieur de la Peche, Cemagref \& Ministére de l'Environment. p. 111.

Klemetsen, A., Amundsen, P.A., Dempson, J.B., Jonsson, B., Jonsson, N., O'connell, M.F., Mortensen, E. (2003). Atlantic salmon (Salmo salar L.), brown trout (Salmo trutta L.) and Arctic charr (Salvelinus alpinus L.): a review of aspects of their life histories. Ecology of Freshwater Fish, 12(1), 159.

https://doi.org/10.1034/j.1600-0633.2003.00010.x 
Khodorevskaya, R.P., Pavlov, D.S., Ruban, G.J. (2009). Behaviour, migrations, distribution, and stocks of sturgeons in the Volga-Caspian Basin. Neu Wulmstorf; World Sturgeon Conservation Society Special Publication, No. 3, p. 233.

Kocabaş, M. (2009). Türkiye doğal alabalık (Salmo trutta) ekotiplerinin kültür şartlarında büyüme performansı ve morfolojik özelliklerinin karşılaştırılması. Karadeniz Teknik Üniversitesi Fen Bilimleri Enstitüsü, Balıkçılık Teknolojisi Mühendisliği Anabilim Dalı, Doktora Tezi,Trabzon, p. 110.

Kolman, R., Zarkua, Z. (2002). Environmental conditions of common sturgeon (Acipenser sturio L.) spawning in River Rioni (Georgia). Electronic Journal of Polish Agricultural Universities, Fisheries, 5(2), 1-9.

Kuru, M. (2004). Türkiye içsu balıklarının son sistematik durumu, Gazi Eğitim Fakültesi Dergisi, 24(3), 1-21.

Küçük, F., Gülle, İ., Güçlü, S.S., Atalay, M.A. (2016). Antalya havzası'ndaki elver göçleri ve habitatları üzerine antropojenik baskılar. Balık Geçitleri ve Göçleri Çalıştayı, 2122 Kasim 2016, İstanbul.

McClave, J.D., Brickley, P.J., O'Brien, K.M., Kistner, D.A., Wong, M.W., Gallagher, M., Watson, S.M. (1988). Do leptocephali of the European eel swim to reach continental waters. Status of the question. Journal of the Marine Biological Association of the United Kingdom, 78(1), 285-306. https://doi.org/10.1017/S0025315400040091

McDowall, R. M. 1988. Diadromy in Fishes: Migrations between Freshwater and Marine Environments. Timber Press, p. 308, Portland, OR.

Memis, D. (2014). A short history of sturgeon caviar production in Turkey. Journal of Applied Ichthyology, 30(6), 15521556.

https://doi.org/10.1111/jai.12602

Memis, D., Tosun, D.D., Yamaner, G., Tunçelli, G., Gessner, J. (2019). Present status of sturgeon in the lower Sakarya River in Turkey. Aquatic Research, 2(2), 53-60. https://doi.org/10.3153/AR19007

Moriarty, C., Dekker, W. (1997). Management of the European eel. Marine Institute, Fisheries Bulletin, 15, 110.
Oray, I. R. (1987). Research on European eel (A.anguilla) catching in inland waters of East Mediterrenaen Region. $\dot{I}_{s-}$ tanbul Üniversitesi Su Ürunleri Fakültesi Dergisi, 1(1), 4369.

Özden, Ö., Can, İ., Oray, I. K., Kaplan, M., Parıldar, S., Erkan Özden, N. (2018). Toxic metal risk assessment of European eels (Anguilla anguilla) in Asi River. 2nd International Fisheries Symposium, p.40, Girne, Kıbrıs.

Rosenthal, H., Gessner, J., Deniz, H., Memiş, D., Ustaoğlu Tirıl, S., Zengin, M., Altan, O. (2015). National action plan for the conservation and restoration of the sturgeons of Turkey. (Edits: Rosenthal, H., Gessner, J), Ministry of Food Agriculture and Livestock, DG Fisheries and Aquaculture, Medisan Yayınevi, p. 127, Ankara.

Secor, D. H. (2015). Migration Ecology of Marine Fishes. Johns Hopkins University Press 2715 North Charles Street Baltimore, Maryland, ISBN 978-1-4214-1613-7.

Tesch, F.W. (1977). The eel biology and management of Anguillid eel. (J. Greenwood, translator) John Wiley and Sons, p. 434, New York.

https://doi.org/10.1007/978-94-009-5761-9

Tunçelli, G., Memiş, D. (2020). Effects of constant and changing water temperature on sperm quality of the endangered Çoruh trout, Salmo coruhensis. Journal of Applied Aquaculture, https://doi.org/10.1080/10454438.2020.1738303

Turan, D., Kottelat, M., Engin, S. (2009). Two new species of trouts, resident and migratory, sympatric in streams of northern Anatolia (Salmoniformes: Salmonidae). Ichthyological Exploration of Freshwaters, 20(4), 333-364.

Ustaoğlu Tırıl, S., Memiş, D. (2018). An overview of the factors affecting the migration of sturgeons in Yeşilırmak. Aquatic Sciences and Engineering, 33(4), 138144.

https://doi.org/10.26650/ASE20180002

Zengin, M., Ustaoglu, T. S., Dagtekin, M., Eryildirim, H., Taner, C., Mehmet, G. (2008). A study on the current status of sturgeon populations in the Kizilirmak and Yesilirmak basins at the beginning of 2000. Workshop on Sturgeon Conservation Strategy and Aquaculture, Ministry of Agriculture and Rural Affairs, Trabzon Central Fisheries Research Institute, 30-31 October 2008, Samsun. 